\title{
Ethanol Production from Cassava Pulp by a Newly Isolated Thermotolerant Pichia kudriavzevii LC375240
}

\author{
Ifeanyi A. Ndubuisi'1, Julius E. Nweze ${ }^{1}$, Nnaemeka J. Onoyima1, Murata Yoshinori², \\ James C. Ogbonna ${ }^{1^{*}}$ \\ ${ }^{1}$ Department of Microbiology, University of Nigeria, Nsukka, Nigeria \\ ${ }^{2}$ Biological Resources and Post-Harvest Division, Japan International Research Center for Agricultural Sciences (JIRCAS), \\ Tsukuba, Japan \\ Email: james.ogbonna@unn.edu.ng
}

How to cite this paper: Ndubuisi, I.A., Nweze, J.E., Onoyima, N.J., Yoshinori, M. and Ogbonna, J.C. (2018) Ethanol Production from Cassava Pulp by a Newly Isolated Thermotolerant Pichia kudriavzevii LC375240. Energy and Power Engineering, 10, 457-474. https://doi.org/10.4236/epe.2018.1010029

Received: September 7, 2018

Accepted: October 28, 2018

Published: October 31, 2018

Copyright $\odot 2018$ by authors and Scientific Research Publishing Inc. This work is licensed under the Creative Commons Attribution International License (CC BY 4.0).

http://creativecommons.org/licenses/by/4.0/

\begin{abstract}
A total of 500 thermotolerant fermenting yeast isolates (100 from palm-wine and 400 from spoilt fruits) were screened for ethanol production at high temperatures. The best isolate that produced up to $4 \%$ ethanol from $10 \%$ glucose at $45^{\circ} \mathrm{C}$ was selected for further experiments. The optimum $\mathrm{pH}$ for ethanol production by the isolate was $\mathrm{pH} 6$ at both $30^{\circ} \mathrm{C}$ and $42^{\circ} \mathrm{C}$. The isolate was identified as Pichia kudriavzevii base on the 18s ribosomal DNA. Ethanol production from $200 \mathrm{~g} / \mathrm{L}$ cassava pulp using Simultaneous Saccharification and Fermentation (SSF) method at $30^{\circ} \mathrm{C}$ and $42^{\circ} \mathrm{C}$ by the isolate was investigated. At $30^{\circ} \mathrm{C}$, an ethanol concentration of $30 \mathrm{~g} / \mathrm{L}$ was produced. This represents an ethanol yield of $0.15 \mathrm{~g} / \mathrm{g}$ of cassava pulp and $58.8 \%$ of the theoretical yield. However at $42^{\circ} \mathrm{C}$, the concentration of ethanol produced increased to $42 \mathrm{~g} / \mathrm{L}$ representing an ethanol yield of $0.21 \mathrm{~g} / \mathrm{g}$ of cassava pulp and $82.4 \%$ of the theoretical yield. The isolate produced slightly higher ethanol than the two typed strains NCYC 587 and NCYC 2791 at $42^{\circ} \mathrm{C}$. This isolate has a good potential to be used for commercial bioethanol production since it can produce ethanol at $45^{\circ} \mathrm{C}$ without a significant drop in ethanol yield.
\end{abstract}

\section{Keywords}

Bioethanol, Cassava Pulp, Yeast, Thermotolerant, Pichia kudriavzevii

\section{Introduction}

The use of bio-ethanol as an alternative to fossil fuel has been gaining worldwide attention owing to its many advantages (renewability, sustainability and envi- 
ronmentally friendliness) over fossil fuel. Despite the many advantages of bio-ethanol, the current costs of production are still much higher than the cost of fossil fuel, thereby limiting its commercialization in many parts of the world. Currently, for large scale production of bio-ethanol, food crops such as corn, sucrose containing feedstock such as sugarcane [1] [2], as well as starchy materials such as cassava [3] are used as raw materials. Aside from direct competition with food, these raw materials are too expensive to compete with the current fossil fuel prices. Lignocellulosic materials on the other hand are cheap and abundant but the cost of converting them to bio-ethanol is high.

Cassava pulp is a promising feedstock for commercial production of bio-ethanol and other value-added bio-products. It is a residue material that is produced as a waste when starch is extracted from cassava. It is cheap and available throughout the year because cassava which is the source of cassava pulp is flexible in terms of planting and harvesting seasons [4] [5] [6] [7]. Also, cassava can grow on arid and semiarid land with moderate yield [8], does not require much input of fertilizer and has little application in food industry. Cassava pulp contains about $40 \%$ $70 \%$ starch on a dry weight basis, $20 \%-30 \%$ cellulose fiber and other non-starch polysaccharides, with moisture content of 70\% - 80\% [5] [9] [10]. Due to its high starch and moisture content, it spoils rapidly and causes environmental problems including strong and offensive odour and contamination of local water supply [11] [12]. Currently, Nigeria is the largest producer of cassava in the world [13]. The waste generated from cassava presently is already posing disposal and environmental problems. With the quest to expand cassava production and processing in Nigeria, a lot of cassava pulps will be generated which if not utilized will result in a lot of environmental pollution. Besides, converting this waste to wealth will greatly improve the economic feasibility of cassava processing industries as well as provide jobs for the many unemployed.

Hydrolysis is the first step in conversion of cassava pulp to bio-ethanol. Due to environmental problems associated with acid/base hydrolysis, attention is now focused on biological hydrolysis using purified or crude enzymes, or hydrolytic enzyme-producing microorganisms. The optimal temperatures for most of the carbohydrate hydrolyzing enzymes are usually higher than the optimal temperatures for the conventional yeast strains used to convert the products of hydrolysis to ethanol. Although conversion of cassava pulp to ethanol can be done in two sequential steps of hydrolysis followed by fermentation, many reports have demonstrated that simultaneous hydrolysis and fermentation leads to higher productivities and yields [14]. However, the use of Simultaneous Saccharification and Fermentation process requires a yeast strain capable of growing, fermenting sugars as well as producing high concentration of ethanol at temperatures close to the temperature of hydrolysis [15]. Also, the use of thermo-tolerant yeast will save cost of cooling especially in tropical climates where ambient temperature can easily exceed $40^{\circ} \mathrm{C}$ [16]. There have been documentations on thermotolerant yeast strains capable of producing ethanol at a temperature up to $42^{\circ} \mathrm{C}$ [14] [17] [18] [19] among others. However, these yeasts have 
not yet been reported for commercial bioethanol production and they are not as robust as Saccharomyces cerevisiae in terms of ethanol production. Thus, there is need to screen for more thermotolerant yeast strains for industrial production of bioethanol. The aim of this work is to screen for thermotolerant ethanol fermenting yeasts and evaluate their potentials for bioethanol production from cassava pulp.

\section{Materials and Methods}

\subsection{Samples}

Palm wine was collected from wine tappers at Enugu-Ezike while spoilt fruits (mostly soursop) were collected from the middle of compost heaps in and around University of Nigeria Nsukka. All samples were collected into sterile containers and transported to the Microbiology laboratory for treatment and isolation of the yeast strains. Cassava pulp was obtained from Nigeria Starch Mill in Iheala, Anambra state Nigeria. The pulps were sun-dried to constant weight, milled, sieved and stored in a refrigerator until used.

\subsection{Isolation of Thermotolerant Fermenting Yeasts}

The samples for yeast isolation were inoculated into an enrichment medium containing $10 \%$ glucose, $2 \%$ peptone and $1 \%$ yeast extract (10\% YPD) and incubated at $42^{\circ} \mathrm{C}$ for 24 hours. A $100 \mu \mathrm{L}$ aliquot of the 24 hours old enrichment culture was spread on agar plates containing $2 \%$ glucose, $2 \%$ peptone, $2 \%$ agar-agar and $1 \%$ yeast extract. The plates were incubated at $42^{\circ} \mathrm{C}$ for 24 hours. After incubation, discrete colonies were picked and inoculated into tubes containing $3 \mathrm{ml}$ of $10 \% \mathrm{YPD}$ and incubated at $30^{\circ} \mathrm{C}$. Isolates showing signs of fermentation after 24 hours of incubation were sub-cultured into a fresh $10 \%$ YPD and incubated at $42^{\circ} \mathrm{C}$ for 24 hours. Isolates showing signs of fermentation after incubation at $42^{\circ} \mathrm{C}$ were sub-cultured into a fresh $10 \%$ YPD in a 96 culture well plate, incubated at $30^{\circ} \mathrm{C}$ for 24 hours and stored at $4^{\circ} \mathrm{C}$ as stock culture for further use. Prior to use, the stock culture from $4^{\circ} \mathrm{C}$ was left at room temperature for 2 hours. A $10 \mu \mathrm{L}$ aliquot of each isolate from the stock culture was inoculated into $180 \mu \mathrm{L}$ of $10 \%$ YPD in a 96 culture well plate using a multichannel pipette. The plates were incubated at $30^{\circ} \mathrm{C}$ for 16 hours.

\subsection{Screening the Isolates for Ethanol Production at High Temperatures}

A $10 \mu \mathrm{L}$ aliquot of each isolate from 16 hours old pre-cultures was inoculated into $180 \mu \mathrm{L}$ of $10 \%$ YPD in a 96 culture well plate using a multichannel pipette. The plates were incubated at $42^{\circ} \mathrm{C}$ for 24 hours. After incubation, the concentration of ethanol produced by each isolate was determined.

\subsection{Rough Screening of the Isolates by NBT/PMS}

This was done using a colorimetric method called Nitroblue Tetrazolium/Phenazine 
Methosulfate (NBT/PMS) according to Johannes et al. [20]. After incubation, the culture was diluted 50 times using distilled water in a 96 culture well plate. Ethanol standards $(0.005 \%, 0.01 \%, 0.02 \%, 0.05 \%$ and $0.1 \%)$ were also prepared and also placed in different wells. A $100 \mu \mathrm{L}$ of $0.1 \mathrm{M} \mathrm{Na-Phosphate} \mathrm{buffer,} \mathrm{pH}$ 7.5 containing $0.1 \%$ Triton X100, $20 \mu \mathrm{L}$ of $0.4 \% \mathrm{NAD}^{+}$and $20 \mu \mathrm{L}$ of Alcohol Dehydrogenase $(10 \mathrm{U} / \mathrm{mL})$ were added in each well. The content of each well was mixed well by repeated pipetting and dispensing, and then the plates were incubated at room temperature for 5 mins. After incubation, $20 \mu \mathrm{L}$ of $0.01 \%$ PMS/0.1\% NBT mixture was added to each well and the plates were incubated at room temperature for 5 mins. The color intensity was compared with that of the different ethanol standards used. The screening was done at $42^{\circ} \mathrm{C}$ and the best 10 stains were isolated.

\subsection{Confirmation of the Ethanol Production Abilities of the Isolates}

The isolates (S26 and P27) were activated in YPD medium for 16 hours, and inoculated into a fresh $3 \mathrm{~mL} \mathrm{10 \%} \mathrm{YPD} \mathrm{to} \mathrm{an} \mathrm{optical} \mathrm{density} \mathrm{(OD)} \mathrm{of} 0.2$ at $600 \mathrm{~nm}$. The tubes were incubated at $42^{\circ} \mathrm{C}$ or $45^{\circ} \mathrm{C}$. The percentage concentration of ethanol produced by each strain was measured using High Performance Liquid Chromatography (HPLC) after 16 and then 24 hours. The best isolate was then used for subsequent experiments.

\subsection{Identification of the Isolate}

Genome DNA was extracted from 24 hours old pure culture of the isolate according to Dhaliwal et al. [17]. About $15 \mathrm{~mL}$ of 24 hours old culture in YPD broth was centrifuged at $3000 \mathrm{~g}$ for 10 minutes and the supernatant was discarded. The precipitate was washed severally by re-suspending in sterile distilled water, centrifuging at $3000 \mathrm{~g}$ and discarding the supernatant. After washing, the precipitate was re-suspended in $2 \mathrm{~mL}$ of set buffer $(20 \mathrm{mM}$ Tris- $\mathrm{HCl}, \mathrm{pH} 7.5,1.2$ $\mathrm{M}$ sorbitol, $10 \mathrm{mM}$ EDTA) and $100 \mu \mathrm{L}$ of zymolyase $(1.0 \mathrm{mg} / \mathrm{mL})$ was added. The mixture was incubated at $30^{\circ} \mathrm{C}$ for 30 minutes. After incubation, $200 \mu \mathrm{L}$ of $10 \%$ SDS (Sodium Dodecyl Sulfate) was added to the mixture, followed by the addition of $2 \mathrm{~mL}$ phenol-chloroform isoamylalcohol (NIPPON GENE, Tokyo, Japan). The mixture was centrifuged at $6000 \mathrm{~g}$ for 15 minutes after vigorous agitation. The clear aqua phase of the supernatant was transferred into a new tube and $10 \mu \mathrm{L}$ of RNAse was added to it. It was incubated at $37^{\circ} \mathrm{C}$ for 2 hours. After incubation, $1 \mathrm{~mL}$ of phenol-chloroform was added to the mixture followed by centrifugation at $6000 \mathrm{~g}$ for 15 minutes. The clear aqua phase of the supernatant was transferred into a clean tube where one-tenth volume $(150 \mu \mathrm{L})$ of $3 \mathrm{M}$ sodium acetate and $4.5 \mathrm{~mL}$ of $100 \%$ ethanol were added. The mixture was centrifuged at $6000 \mathrm{~g}$ and supernatant was discarded. To the DNA precipitate, $2 \mathrm{~mL}$ of cold $80 \%$ ethanol was added, it was centrifuged for 5 minutes and the supernatant was discarded. The DNA was air-dried at room temperature for 10 minutes 
and re-suspended in sterile distillate water. Polymerase Chain Reaction (PCR) amplification of 18s ribosomal Ribonucleic Acid (rRNA) gene was carried out on the isolated DNA using Internally Transcribed Spacer (ITS) primer. Both ITS4 (5'TCCTCCGCTTATTGATATGC3') and ITS5

(5'GGAAGTAAAAGTCGTAACAAGG3') were used for the amplification of appropriate DNA region. The sequence of DNA fragment was decided, and yeast strain was identified by comparison with the sequences of other strains. The evolutionary history of the isolates was inferred using the Neighbor-Joining method according to Saitou and Nei [21]. The tree was drawn to scale, with branch lengths in the same units as those of the evolutionary distances used to infer the phylogenetic tree. The evolutionary distances were computed using the Maximum Composite Likelihood method of Tamura et al. [22] and are in the units of the number of base substitutions per site. The analysis involved 25 nucleotide sequences. Codon positions included were $1 \mathrm{st}+2 \mathrm{nd}+3 \mathrm{rd}+$ Noncoding. All positions containing gaps and missing data were eliminated. There were a total of 500 positions in the final dataset. Evolutionary analyses were conducted in MEGA6 software according to Tamura et al. [23].

\subsection{Characterization of the Isolate}

The isolate was characterized by checking its sugar assimilation profile, temperature tolerance, $\mathrm{pH}$, ethanol and Acetic acid tolerance.

\subsection{Sugar Assimilation Profile}

This was carried out using the Api 20C AUX sugar assimilation kit (Analytab products, Div. of Ayerst Laboratories, Plainview, New York). The isolate was inoculated in $10 \% \mathrm{YPD}$ and incubated at $30^{\circ} \mathrm{C}$ on a rotary shaker at $120 \mathrm{rpm}$ for 8 hours. The OD of the isolates at $600 \mathrm{~nm}$ was adjusted to 0.4 in $0.8 \% \mathrm{NaCl}$. A 100 $\mu \mathrm{L}$ aliquot of the $\mathrm{NaCl}$-diluted sample was transferred into a basal medium containing all the nutrients required for growth except the sugar, and subsequently, a $200 \mu \mathrm{L}$ of this was transferred into each sugar well. The kit was incubated at $30^{\circ} \mathrm{C}$ for 72 hours and the ability of the isolates to assimilate a sugar was inferred by comparing the turbidity in each sugar well with the control.

\subsection{Temperature Tolerance}

The temperature tolerance ability of the isolate was measured by incubating it at different temperatures $\left(30^{\circ} \mathrm{C}, 37^{\circ} \mathrm{C}, 40^{\circ} \mathrm{C}, 42^{\circ} \mathrm{C}, 45^{\circ} \mathrm{C}\right.$ and $\left.47^{\circ} \mathrm{C}\right)$ in $10 \%$ YPD. The isolate was first pre-cultured at $30^{\circ} \mathrm{C}$ for 16 hours. It was inoculated into a fresh 10\% YPD to an OD of 0.2 at $600 \mathrm{~nm}$. The concentration of ethanol produced by the isolate was measured after 24 and 48 hours using HPLC.

\subsection{0. $\mathrm{pH}$ Tolerance}

The $\mathrm{pH}$ tolerance ability of the isolate was measured by inoculating them in $10 \%$ YPD adjusted to different $\mathrm{pH}$ values $(2,4,6,8$ and 10) using either hydrochloric 
acid (for acidic $\mathrm{pH}$ ) or sodium hydroxide (for the alkaline $\mathrm{pH}$ ). This was incubated at $30^{\circ} \mathrm{C}$ or $42^{\circ} \mathrm{C}$ and cultivated for 48 hours. Measurement of concentration of ethanol produced by the isolate was also done using HPLC.

\subsection{Ethanol and Acetic Acid Stress Tolerance}

The growth phenotypes of the isolated strain and two typed strains (NCYC 587 and NCYC 2791) were compared in media containing ethanol and acetic acid. Approximately $2.0-6.0 \times 10^{4}$ cells $(\mathrm{A} 600=1.0)$ of each strain (dilution factor $\left.10^{\circ}\right)$ and those of serially diluted $\left(10^{-1}-10^{-4}\right)$ were spotted onto YPD containing $6 \%(\mathrm{w} / \mathrm{v})$ ethanol, and varied concentrations $(50 \mathrm{mM}, 60 \mathrm{mM}$, and $70 \mathrm{mM})$ of acetic acid. These plates were incubated for 22 hours at $40^{\circ} \mathrm{C}$.

\subsection{Analysis of Starch and Cellulose Contents of the Cassava Pulp}

The starch content was analyzed using the iodine method. One gram $(1 \mathrm{~g})$ of the cassava pulp was homogenized in $70 \mathrm{~mL}$ of distilled water. It was boiled for 30 minutes and allowed to cool. The volume was adjusted to $100 \mathrm{~mL}$ using distilled water. This was centrifuged and $0.1 \mathrm{~mL}$ supernatant was added into a test tube. A $5 \mathrm{~mL}$ of 1:100 dilution (1 mL of iodine solution: $100 \mathrm{~mL}$ of distilled water) of iodine solution was then added to the $0.1 \mathrm{~mL}$ of the supernatant. The volume of the mixture was adjusted to $10 \mathrm{~mL}$ using distilled water and the absorbance was taken at $680 \mathrm{~nm}$. Analysis of cellulose was done according to the methods of Updegraff [24].

\subsection{Production of Koji Enzyme Used for Hydrolysis}

A $30 \mathrm{~g}$ portion of rice and $20 \mathrm{~g}$ of rice bran were steamed together. After steaming, it was allowed to cool to room temperature. Spores of the Aspergillus fumigatus on potato dextrose agar slants were harvested using normal saline and inoculated into the mixture of rice and rice bran. This was covered with muslin cloth and incubated at $30^{\circ} \mathrm{C}$ for 72 hours with daily stirring for effective enzyme production. A $2.5 \mathrm{~g}$ of this koji was used as the source of enzyme throughout the experiment.

\subsection{Pretreatment and Hydrolysis of Cassava Pulp and Glucose Assay}

A $20 \%(\mathrm{w} / \mathrm{v})$ Cassava pulp was pre-treated by autoclaving at $121^{\circ} \mathrm{C}$, and pressure of 15 psi for 10 minutes. It was cooled to room temperature before hydrolysis. A $2.5 \mathrm{~g}$ of the koji enzyme from Aspergillus fumigatus was added to the pre-treated cassava pulp as enzyme for starch hydrolysis throughout the experiment. Cassava pulp without pretreatment $(20 \% \mathrm{w} / \mathrm{v})$ was used as the control. The pre-treated cassava pulp, as well as the control was incubated with $k o j i$ at $42^{\circ} \mathrm{C}$ for 48 hours. After 48 hours, the concentration of the reducing sugar (glucose) released was measured using HPLC. 


\subsection{Ethanol Production from Cassava Pulp by Pichia kudriavzevii S26, K. marxianus NCYC 587, and NCYC2791}

The pretreated cassava pulp (20\% w/v) was supplemented with $2 \%$ polypeptone and $1 \%$ yeast extract before fermentation. Yeast strains (S26, NCYC587, and NCYC2791) were pre-cultured in YPD. The pre-cultured yeasts were inoculated into the pretreated cassava pulp $(20 \% \mathrm{w} / \mathrm{v})$ to a final OD of 0.6 at $600 \mathrm{~nm}$. These cassava pulps were incubated at $30^{\circ} \mathrm{C}$ and $42^{\circ} \mathrm{C}$. Samples for ethanol detection were taken at every 24 hour, and the concentration of ethanol was analyzed by HPLC (Prominence, Shimazu Seisakusho, Kyoto, Japan), using Aminex HPX87H $(300 \times 7.8 \mathrm{~mm})($ BioRad, California, USA) as the column.

\subsection{Statistical Analysis}

All the experiments were performed three times and the results were presented as mean \pm SD. The data were subjected to Analysis of Variance (single classification) and where significance differences were observed, Least Significance Difference (LSD) was used to separate the means.

\section{Results}

\subsection{Ethanol Production at High Temperatures by the Best Isolates}

A total of 500 colonies ( 100 colonies isolated from palm wine and 400 colonies isolated from spoilt fruits) were obtained. The results of ethanol production by the 10 best isolates, (Table 1 ) at $42^{\circ} \mathrm{C}$ and $45^{\circ} \mathrm{C}$ are shown in Figure 1 . With the exception of $\mathrm{P} 71$, all the isolates produced higher concentration of ethanol at $42^{\circ} \mathrm{C}$ than at $45^{\circ} \mathrm{C}$. However, in some isolates such as P27 and S26, there was no significant difference in the concentration of ethanol produced at $42^{\circ} \mathrm{C}$ and $45^{\circ} \mathrm{C}$ ( $\mathrm{p}>0.05)$. On the whole, isolates $\mathrm{P} 27$ and $\mathrm{S} 26$ produced high ethanol concentration $(>4 \%)$ from $10 \%$ glucose. S26 was selected for further studies because it showed more stable performance in terms of the concentrations of ethanol produced from glucose medium under high temperatures than P27 (Figure 2).

Table 1. The 10 best isolates and their isolation source.

\begin{tabular}{cc}
\hline ISOLATE & ISOLATION SOURCE \\
\hline P83 & Palm wine \\
S67 & Spoilt fruit (soursop) \\
P27 & Palm residue \\
P71 & Palm wine \\
S26 & Spoilt fruit (soursop) \\
S65 & Spoilt fruit (banana) \\
S2 & Spoilt fruit (soursop) \\
S86 & Spoilt fruit (guava) \\
S1 & Spoilt fruit (soursop) \\
P5 & Spoilt fruit (pineapple) \\
\hline
\end{tabular}




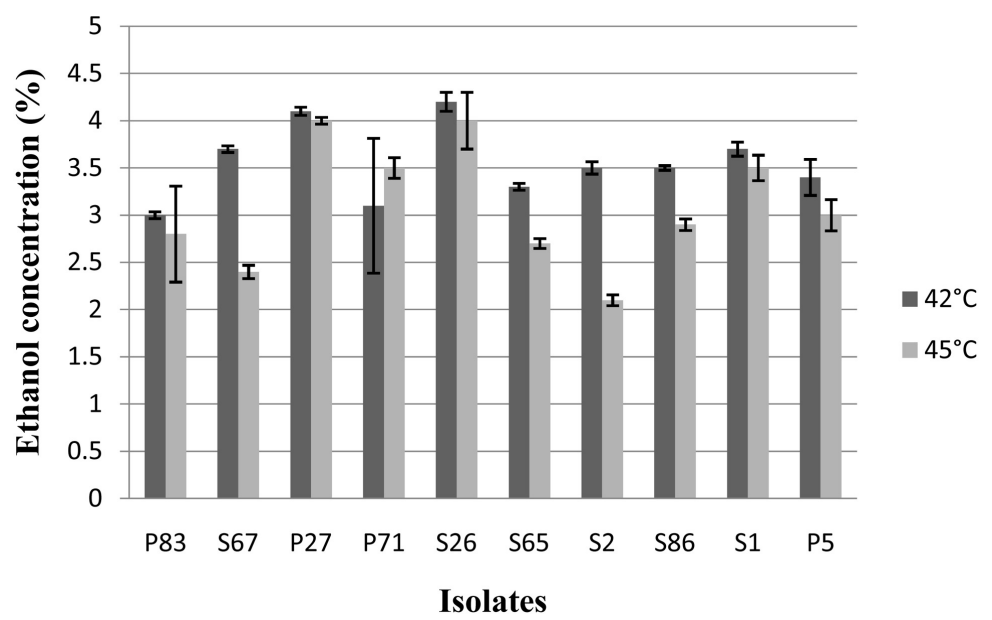

Figure 1. Ethanol production by the 10 best isolates at $42^{\circ} \mathrm{C}$ and $45^{\circ} \mathrm{C}$. The ethanol concentrations were determined after $24 \mathrm{~h}$ of cultivation.

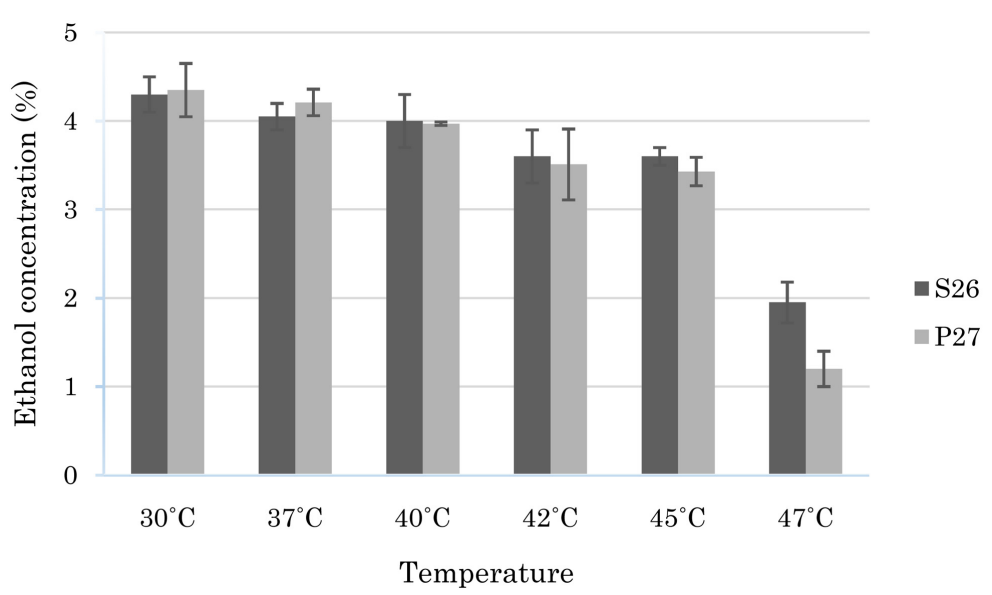

Figure 2. Effect of temperature on ethanol production by isolates S26 and P27. The ethanol concentrations were determined after $24 \mathrm{~h}$ of cultivation.

\subsection{Characterization and Identification of the Isolate}

Isolate S26 was able to assimilate up to 10 sugars (Table 2). It assimilated glycerol as carbon source but was not able to assimilate xylose (Table 2). This sugar assimilation pattern is a characteristic of Pichia kudriavzevii [25].

Time courses of ethanol production by isolate S26 at various temperatures are shown in Figure 3. It produced the highest concentration of ethanol $(4.3 \% \mathrm{w} / \mathrm{v})$ at $30^{\circ} \mathrm{C}$ and the concentration of ethanol decreased gradually as temperature increased. It is important to note that it was able to produce high concentration of ethanol $(3.6 \% \mathrm{w} / \mathrm{v})$ even at $45^{\circ} \mathrm{C}$, corresponding to ethanol yield of $70.6 \%$. There was a significant decrease in the concentrations of ethanol produced by the isolate at $47^{\circ} \mathrm{C}(\mathrm{p}<0.05)$.

The effects of $\mathrm{pH}$ on ethanol production by the isolate at $30^{\circ} \mathrm{C}$ and $42^{\circ} \mathrm{C}$ are shown in Figure 4. As shown in Figure 3, at a pH of 6, the concentrations of ethanol produced at $30^{\circ} \mathrm{C}$ and $42^{\circ} \mathrm{C}$ were $4.3 \%$ and $3.7 \%$, which correspond to ethanol yields of $84.3 \%$, and $72.5 \%$, respectively. At extreme $\mathrm{pH}$ values of 2 and 
Table 2. Sugar assimilation profile of the isolate S26.

\begin{tabular}{cc}
\hline Sugars & Degree of assimilation \\
GLUCOSE & +++ \\
GLYCEROL & -++ \\
2KG & --+ \\
ARABINOSE & --- \\
XYLOSE & -++ \\
ADOLOSE & -++ \\
XYLITOL & +++ \\
GALACTOSE & --- \\
INOSITOL & -++ \\
SORBITOL & -- \\
MDG & -- \\
NAG & -- \\
CEL & --+ \\
LACTOSE & --+ \\
MALTOSE & +++ \\
SACROSE & --- \\
TRE & -- \\
MLZ & -++ \\
RAF & +- \\
\hline
\end{tabular}

$+++=$ high assimilation; $-++=$ moderate assimilation; $--+=$ low assimilation, and $---=$ no assimilation.

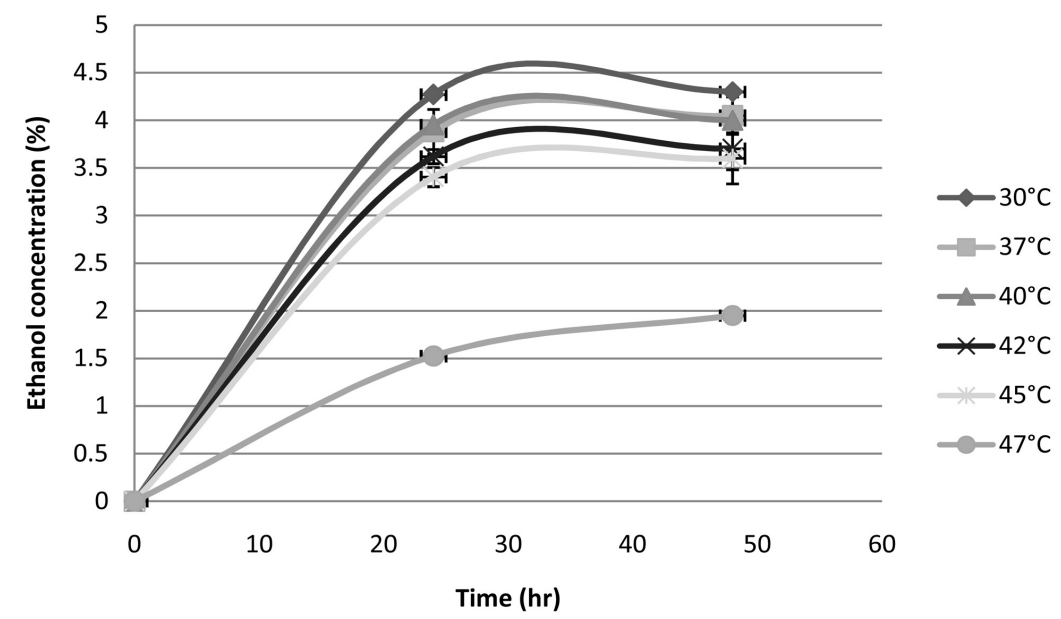

Figure 3. Effect of temperature on ethanol production from $10 \%$ YPD by isolate S26.

10, S26 was not able to produce ethanol.

The effect of ethanol and acetic acid on the growth of the isolate is shown in Figure 5. The isolate was able to grow on YPD supplemented with $6 \%$ ethanol as well as the one supplemented with $70 \mathrm{mM}$ acetic acid. It also exhibited higher tolerance to acetic acid and ethanol than NCYC587 and NCYC2791 (Figure 5). 


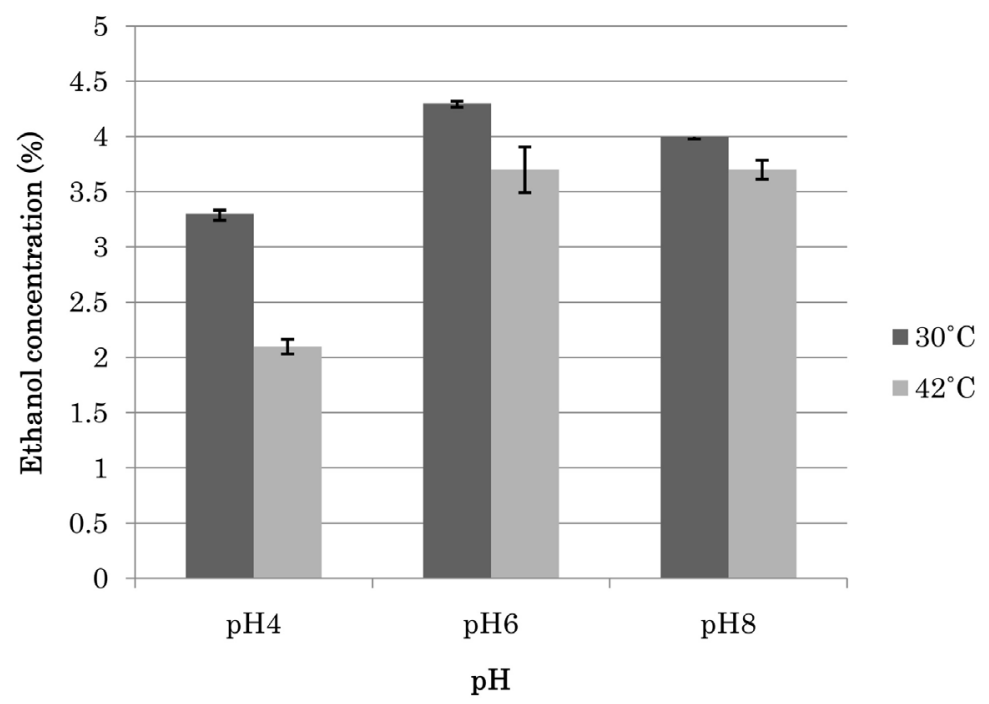

Figure 4. Effect of $\mathrm{pH}$ on ethanol production by the isolate $\mathrm{S} 26$ at $30^{\circ} \mathrm{C}$ and $42^{\circ} \mathrm{C}$. The ethanol concentrations were determined after $24 \mathrm{~h}$ of cultivation.

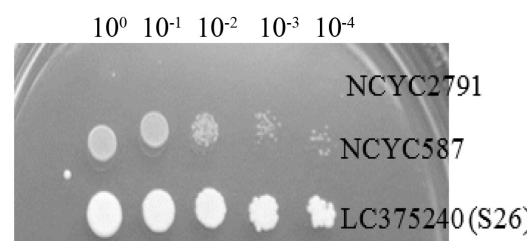

YPD+50mM Acetic acid

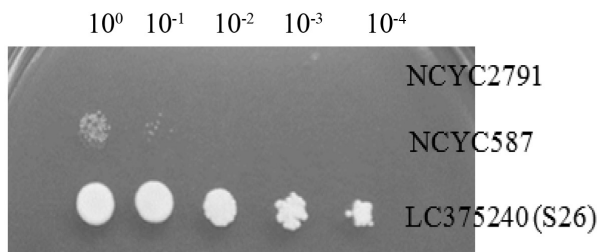

YPD+70mM Acetic acid

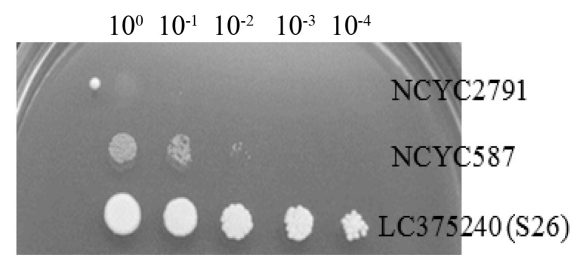

YPD+60mM Acetic acid

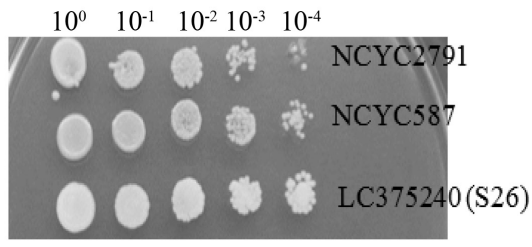

YPD $+6 \%$ Ethanol

Figure 5. Effects of acetic acid and ethanol on the colony growth of the isolate, LC375240(S26), NCYC 2791 and NCYC 587 on YPD plates. The undiluted $\left(10^{\circ}\right)$ and serially diluted yeast cells were plated YPD plates containing various concentrations of acetic acid or $6 \%$ ethanol and incubated at $40^{\circ} \mathrm{C}$ for $24 \mathrm{~h}$. The results show that NCYC2791 was very sensitive to acetic acid and was completely inhibited even when undiluted broth $\left(10^{\circ}\right)$ was plated. On the other hand, LC375240 (S26) was resistant to acetic acid and grew well in the presence of $70 \mathrm{mM}$ acetic acid and $6 \%$ ethanol.

While NCYC2791 was not able to grow on YPD containing $70 \mathrm{mM}$ acetic acid, our isolate (S26) grew very well even when diluted to $10^{-4}$ (Figure 5).

Phylogenetic tree for the isolate was constructed from the sequence and blast search result by using MEGA6 software (Figure 6). The isolate (S26) was grouped with the clade of Pichia kudriavzevii. This result agreed with the data on sugar assimilation (Table 2). Consequently, the isolate, S26, was identified as Pichia kudriavzevi, and it was registered as LC375240 at Genebank. 


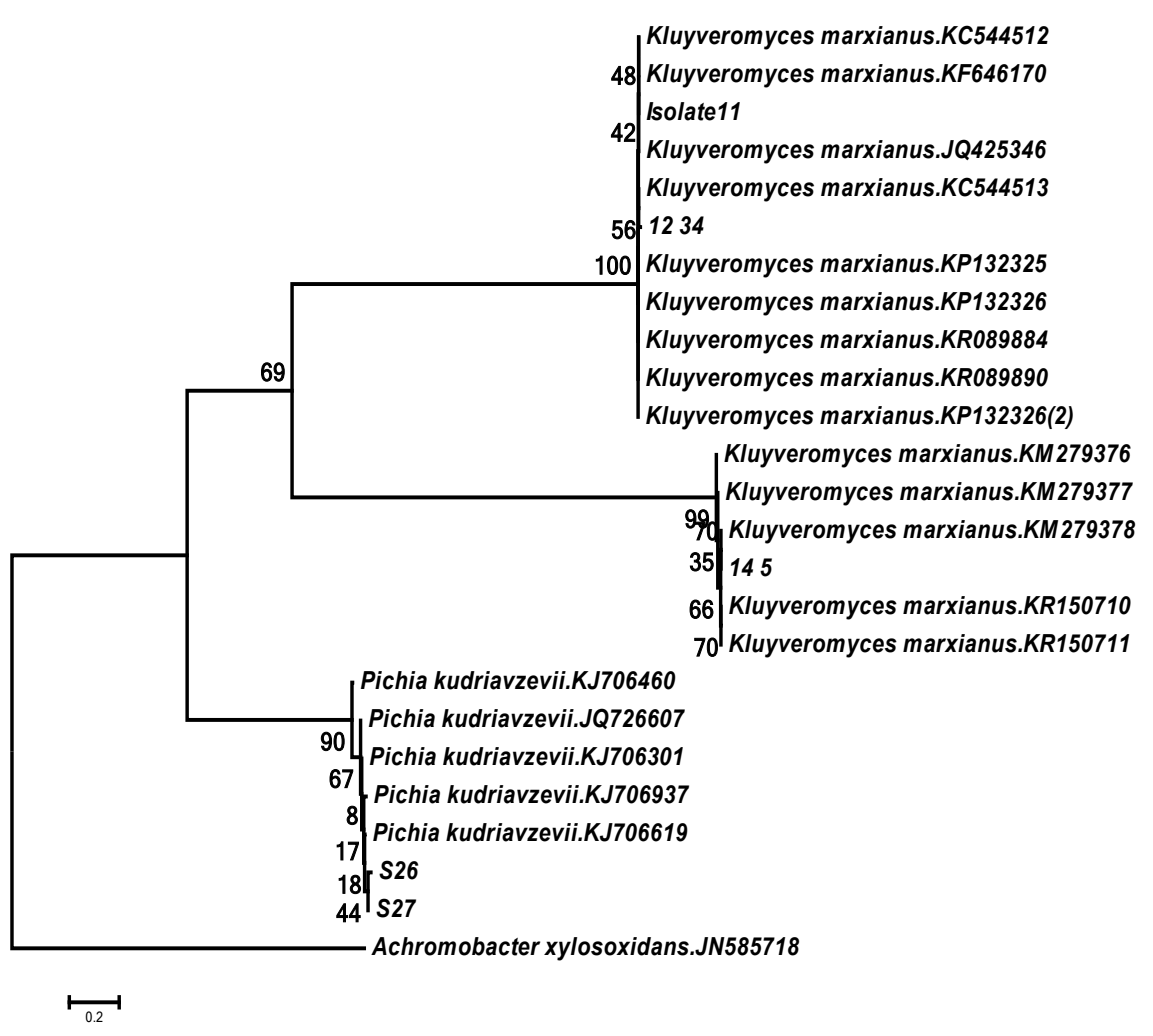

Figure 6. Phylogenetic tree of the isolates.

\subsection{Ethanol Production from Cassava Pulp}

The starch and cellulose contents of dried cassava pulp from Nigeria Starch Mill, Iheala were $48.6 \% \pm 4.0 \%$ and $21.5 \% \pm 2.0 \%$ respectively. The cassava pulp $(20 \%$ $\mathrm{w} / \mathrm{v})$ was pre-treated by autoclaving at $121^{\circ} \mathrm{C}$ for 20 minutes and hydrolyzed using Aspergillus fumigatus koji. After 24 hours of hydrolysis, the concentration of glucose increased from $0.69 \pm 0.05$ to $10.09 \pm 0.05$ while the concentration of starch decreased from $9.66 \pm 0.2$ to $0.56 \pm 0.02$ (Table 3). Besides, little sugar was detected in cassava pulp without pretreatment (data not shown). The results of Simultaneous Saccharification and Fermentation of $20 \%$ cassava pulp using koji and each of the yeast strains (S26, NCYC587, NCYC2791) are shown in Figure 7. S26 produced higher concentration of ethanol at $42^{\circ} \mathrm{C}(4.2 \% \pm 0.03 \%)$ than at $30^{\circ} \mathrm{C}(3.0 \% \pm 0.06 \%)$. A comparison of ethanol production ability of S26 with those of known thermotolerant strains of Kluyveromyces marxianus is shown in Figure 8. All the three strains (S26, K. marxianus NCYC587 and NCYC2791) produced higher ethanol concentrations of $4.2 \%, 4.0 \%$ and $3.7 \%$, respectively, at $42^{\circ} \mathrm{C}$ than at $30^{\circ} \mathrm{C}$. These correspond to ethanol yields of $82.3 \%$, $78.4 \%$ and $72.5 \%$, respectively (Figure 8). These results demonstrated that the new isolate (S26) has a great potential for ethanol production from cassava pulp at high temperatures.

\section{Discussion}

Pichia kudriavzevii which is able to grow and produce ethanol within a temperature 
Table 3. Effect of autoclaving for 10 minutes and hydrolysis using Aspergillus fumigatus koji on the composition of $20 \%$ (w/v) cassava pulp.

\begin{tabular}{ccc}
\hline Components & Initial & $24 \mathrm{~h}$ after hydrolysis \\
\hline Starch & $9.66 \pm 0.2$ & $0.56 \pm 0.02$ \\
Cellulose & $1.64 \pm 0.03$ & $0.49 \pm 0.01$ \\
Glucose & $0.69 \pm 0.05$ & $10.09 \pm 0.05$ \\
\hline
\end{tabular}

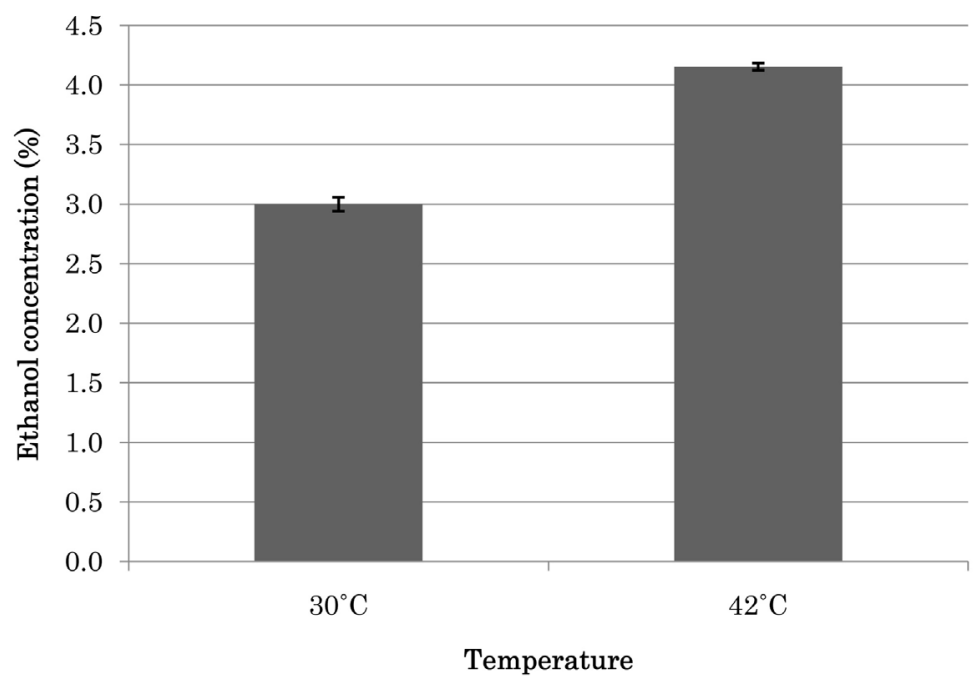

Figure 7. Ethanol production from cassava pulp at $30^{\circ} \mathrm{C}$ and $42^{\circ} \mathrm{C}$ by the isolated Pichia kudriavzevii S26 (LC375240) using SSF. The ethanol concentrations were determined after $24 \mathrm{~h}$ of fermentation.

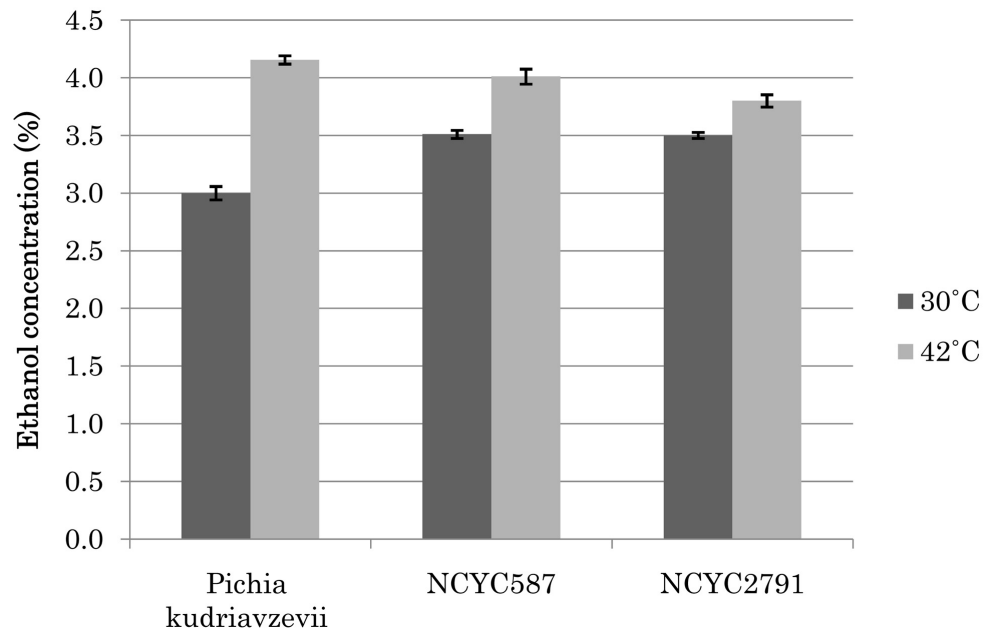

Figure 8. Comparison of ethanol production abilities of the P. kudriavzevii S26 (LC375240) and some typed strains from cassava pulp using SSF at $30^{\circ} \mathrm{C}$ and $42^{\circ} \mathrm{C}$ ( $K$. marxianus NCYC587 and NCYC2791). The ethanol concentrations were determined after $24 \mathrm{~h}$ of fermentation.

range of $30^{\circ} \mathrm{C}$ and $47^{\circ} \mathrm{C}$ was isolated in this study. This conforms the previous reports that many thermo-tolerant strains of this yeast grow well at temperatures as high as $45^{\circ} \mathrm{C}$ to $52^{\circ} \mathrm{C}$ and can efficiently ferment and produce ethanol at tem- 
peratures of between $38^{\circ} \mathrm{C}$ and $45^{\circ} \mathrm{C}$ [14] [18] [26] [27] [28].

Using $20 \%$ cassava pulp supplemented with $1 \%$ yeast extract and $2 \%$ peptone at $42^{\circ} \mathrm{C}$, the isolate produced $42 \mathrm{~g} / \mathrm{l}$ ethanol representing an ethanol yield of 0.21 g-ethanol/g-cassava pulp using Simultaneous Saccharification and Fermentation method. This was $82.4 \%$ of theoretical ethanol yield. At $30^{\circ} \mathrm{C}$ under the same conditions, the isolate produced $30 \mathrm{~g} / \mathrm{l}$ ethanol representing an ethanol yield of $0.15 \mathrm{~g} / \mathrm{g}$ of cassava pulp and $58.8 \%$ theoretical ethanol yield. It is interesting to note that the ethanol yield was even higher at $42^{\circ} \mathrm{C}$ than at $30^{\circ} \mathrm{C}$. This could be because $42^{\circ} \mathrm{C}$ is closer to the optima temperature for the saccharifing and hydrolytic enzymes and highlights the significance of this study. The temperature inside fermentation tank increases gradually during fermentation but even without temperature control, it does not usually rise above $45^{\circ} \mathrm{C}$. Thus with a thermotolerant yeast which can efficiently produce ethanol within a wide range of temperature (between $35^{\circ} \mathrm{C}$ and $45^{\circ} \mathrm{C}$ ) means that ethanol production can be done without temperature control. In other words, the P. kudriavzevii, S26 (LC375240) isolated in this study has a great potential for commercial ethanol production. This strain produced even higher concentration of ethanol at $42^{\circ} \mathrm{C}$ than at $30^{\circ} \mathrm{C}$ (Figure 3 and Figure 7). When conventional yeast, Saccharomyces cerevisiae, was cultivated consecutively at high temperature, the morphological shape of the cells became elongated [29]. This morphological alteration was observed also observed in $P$. kudriavzevii when it was used for continuous ethanol fermentation under high temperature [30]. The sporadic filamentous cells might be a requirement for tolerance or acquired acclimation in the fermentation system at high temperatures.

The ethanol yields obtained in this study are higher than those reported in some previous works. For example, Kaewkrajay et al. [19] reported that $P$. kudriavzevii PBB511-1 produced $37.0 \mathrm{~g} / \mathrm{l}$ ethanol with $40 \%$ of theoretical yield in a cassava starch hydrolysate medium containing reducing sugar (180 g/l ), $\left(\mathrm{NH}_{4}\right)_{2} \mathrm{SO}_{4}(0.5 \mathrm{~g} / \mathrm{l}), \mathrm{KH}_{2} \mathrm{PO}_{4}(0.5 \mathrm{~g} / \mathrm{l}), \mathrm{MgSO}_{4} \cdot 7 \mathrm{H}_{2} \mathrm{O}(0.5 \mathrm{~g} / \mathrm{l})$, and yeast extract $(1.0 \mathrm{~g} / \mathrm{l})$ at $45^{\circ} \mathrm{C}$. Yuangsaard et al. [18] reported that $P$. kudriavzevii DMKU 3-ET15 (isolated from traditional fermented pork sausage) could produce ethanol from cassava starch hydrolysate medium composed of $18 \%$ glucose, $0.05 \%$ $\left(\mathrm{NH}_{4}\right)_{2} \mathrm{SO}_{4}, 0.09 \%$ yeast extract, $0.05 \% \mathrm{KH}_{2} \mathrm{PO}_{4}$, and $0.05 \% \mathrm{MgSO}_{4} \cdot 7 \mathrm{H}_{2} \mathrm{O}$ but at $45^{\circ} \mathrm{C}$, only $4 \%(\mathrm{w} / \mathrm{v})$ ethanol, ( $42 \%$ of theoretical yield) was produced. Dhaliwal et al. [17] reported isolation of $P$. kudriavzevii from sugarcane juice which at $40^{\circ} \mathrm{C}$, produced $71.9 \mathrm{~g} / \mathrm{l}$ of ethanol and a productivity of $4.0(\mathrm{~g} / \mathrm{l} \cdot \mathrm{h})$ from sugarcane juice composed of $14 \%(\mathrm{w} / \mathrm{v})$ sucrose, $2 \%(\mathrm{w} / \mathrm{v})$ glucose, and $1 \%(\mathrm{w} / \mathrm{v})$ fructose. Oberoi et al. [28] reported isolation of a thermo-tolerant $P$. kudriavzevii HOP-1 which produced $24.25 \mathrm{~g} / \mathrm{l}$ of ethanol, corresponding to $82 \%$ of the theoretical ethanol yield on glucan basis from $1 \%$ sodium hydroxide-treated rice straw via simultaneous saccharification and fermentation at $40^{\circ} \mathrm{C}$. However, some reports have also shown that higher ethanol concentrations and yields can be obtained with $P$. kudriavzevii species. For example, Yuangsaard et al. [18] re- 
ported an ethanol theoretical yield of $85.4 \%$ using P. kudriavzevii DMKU 3-ET15 (isolated from traditional fermented pork sausage) at $40^{\circ} \mathrm{C}$. On the whole, the final ethanol concentrations and yields depend, not only on the strain, but also on fermentation conditions, especially the nature of substrate. Cassava pulp, which is generated in large quantities in Nigeria and poses a lot of environmental problem was used in this study. The starch content of the pulp (48\%) was lower than those reported in other works [5] [9] [11] [31]. However, the cellulose content $(21.5 \%)$ was higher than the value reported by Rattanachomsri et al. [9] and Virunanon et al. [31]. They reported a cellulose contents of $15.6 \%$ and $4.11 \%$ respectively. Generally, the starch and cellulose contents of cassava pulp depend on the variety of cassava, the age of the cassava and the processing method. Nevertheless, the present study has demonstrated that cassava pulp is a good substrate for ethanol production.

Nigeria remains the world largest producer of cassava and in 2016, she produced a total of 57,134,478 tons. With the technology currently used to produce cassava starch in Nigeria, $400 \mathrm{~kg}$ of pulp is produced per ton of cassava tubers (on wet weight basis) and assuming 60\% water content of the pulp, $160 \mathrm{~kg}$ of dry pulp is produced per ton of cassava tubers. If only $20 \%$ of cassava tubers $(11,426,895$ tons of cassava tubers) is processed into starch, $1,828,303$ tons of dry pulp will be produced. With the current yield of 0.21 g-ethanol/g-pulp and assuming ethanol density of $0.789 \mathrm{~mL} / \mathrm{g}, 266 \mathrm{~L}$ of anhydrous ethanol will be produced per ton of dry pulp. Thus, it is estimated that 486,328,598 $\mathrm{L}$ of ethanol will be produced from the pulp generated from $20 \%$ of cassava produced in Nigeria. Currently, Nigerian local refineries are producing only about 8 million liters of Premium motor spirit (PMS) per day. This requires only 800,000 liters of ethanol per day (292,000,000 L per annum) to make E10 (90\% gasoline: $10 \%$ ethanol) and can be supplied by converting pulp from only $12 \%$ of cassava produced in Nigeria. Cassava pulp, being a waste, is usually exposed to many kinds of microorganisms and thus contains high levels of organic acids (lactic acid or acetic acid). These organic acids inhibit ethanol fermentation [32]. However, our isolated $P$. kudriavezevii can grow on YPD supplemented with $70 \mathrm{mM}$ acetic acid even at $10^{-4}$ dilution. It has also been known that $P$. kudriavezevii has high tolerance to organic acids, and it was able to produce ethanol from YPD medium containing $50 \mathrm{mM}$ acetic acid [33]. Therefore, $P$. kudriavzevii, S26 a robust yeast for ethanol production without proper sterilization of cassava pulp.

It is also important to note that the isolate obtained in the present study gave higher ethanol yield than those of the typed ethanol-fermenting thermo-tolerant strains of Kluveromyces maxianus from the National Collection of Yeast Cultures Institute in the United Kingdom (NCYC 2791 and NCYC 587) under the same culture conditions. This yeast strain thus hold a good potential for large scale bio-ethanol production in tropical areas like Nigeria as they will help reduce the cost of cooling during fermentation, save time, reduce contamination and thus reduce the cost of producing bio-ethanol. 


\section{Conclusion}

A thermo-tolerant ethanol-fermenting strain of Pichia kudriavzevii S26 (LC375240) was isolated from decaying fruits in Nigeria. The potential of the isolate in producing ethanol from cassava pulp was evaluated. Under optimum temperature of $42^{\circ} \mathrm{C}$, the isolate was able to produce 0.21 g-ethanol/g-cassava pulp. It is estimated that with this strain, the amount of ethanol needed to produce E10 from all the PMS locally refined in Nigeria can be produced from cassava pulp generated from only $12 \%$ of cassava tubers produced in Nigeria by Starch Mills. Higher ethanol yields can be obtained by optimizing the pretreatment of cassava pulps to enhance effective conversion of all the starch and non-starch contents of the pulp to fermentable sugars.

\section{Acknowledgements}

This work was supported by a grant from the Ministry of Agriculture, Forestry, and Fisheries of Japan (Development of climate change mitigation technology through effective utilization of agro processing residues). The authors wish to acknowledge the Japan International Research Centre for Agricultural Science (JIRCAS) for funding this work.

\section{Conflicts of Interest}

There is no conflict of interests.

\section{References}

[1] Ogbonna, J.C., Tomiyama, S., Lui, Y.C. and Tanaka H. (1997) Efficient Production of Ethanol by Cells Immobilized in Loofa (Luffa Cylindrica) Sponge. Journal of Fermentation and Bioengineering, 84, 271-274. https://doi.org/10.1016/S0922-338X(97)82069-7

[2] Ogbonna, J.C., Mashima, H. and Tanaka, H. (2001) Scale up of Fuel Ethanol Production from Sugar Beet Juice Using Loofa Sponge Immobilized Bioreactor. Bioresource Technology, 76, 1-8. https://doi.org/10.1016/S0960-8524(00)00084-5

[3] Roble, N.D., Ogbonna, J.C. and Tanaka, H. (2003) A Novel Circulating Loop Bioreactors with Cells Immobilized in Loofa (Luffa cylindrica) Sponge for Bioconversion of Raw Cassava Starch to Ethanol. Applied Microbiology and Biotechnology, 60, 671-678. https://doi.org/10.1007/s00253-002-1119-0

[4] Shetty, J.K., Chotani, G., Duan, G. and Bates, D. (2007) Cassava as an Alternative Feedstock in the Production of Transportation Fuel. International Sugar Journal, 109, 663-677.

[5] Kosugi, A., Akihiko, K., Mitsuyoshi, U., Yoshinori, M., Pilanee, V., Warunee, T., Takamitsu, A. and Yutaka, M. (2009) Production of Ethanol from Cassava Pulp via Fermentation with a Surface-Engineered Yeast Strain Displaying Glucoamylase. Renewable Energy, 34, 1354-1358. https://doi.org/10.1016/j.renene.2008.09.002

[6] Lin, H.J., Xian, L., Zhang, Q.J., Luo, X.M., Xu, Q.S., Yang, Q., Duan, C.J., Liu, J.L., Tang, J.L. and Feng, J.X. (2011). Production of Raw Cassava Starch-Degrading Enzyme by Penicillium and Its Use in Conversion of Raw Cassava Flour to Ethanol. Journal of Industrial Microbiology and Biotechnology, 38, 733-742. 
https://doi.org/10.1007/s10295-010-0910-7

[7] Sidra, P., Aman, A., Iqbal, S., Siddiqui, N.N. and Ali, S. (2014) Saccharification and Liquefaction of Cassava Starch: An Alternative Source for the Production of Bioethanol Using Amylolytic Enzymes by Double Fermentation Process. BMC Biotechnology, 14, 49. https://doi.org/10.1186/1472-6750-14-49

[8] Ogbonna, C.N. and Okoli, E.C. (2013) Economic Feasibility of On-Farm Fuel Ethanol Production from Cassava Tubers in Rural Communities. African Journal of Biotechnology, 12, 5618-5626.

[9] Rattanachomsri, U., Sutipa, T., Lily, E. and Verawat, C. (2009) Simultaneous Non-Thermal Saccharification of Cassava Pulp by Multi-Enzyme Activity and Ethanol Fermentation by Candida Tropicalis. Journal of Bioscience and Bioengineering, 107, 488-493. https://doi.org/10.1016/j.jbiosc.2008.12.024

[10] Apiwatanapiwat, W., Yoshinori, M., Kosugi, A., Ryosuke, Y., Akihiko, K., Takamitsu, A., Prapassorn, R. and Yutaka, M. (2011) Direct Ethanol Production from Cassava Pulp Using a Surface-Engineered Yeast Strain Co-Displaying Two Amylases, Two Cellulases, and $\beta$-Glucosidase. Applied Microbiology and Biotechnology, 90, 377-384. https://doi.org/10.1007/s00253-011-3115-8

[11] Sriroth, K., Rungsima, C., Sunee, C., Kuakoon, P. and Christopher, G.O. (2000) Processing of Cassava Waste for Improved Biomass Utilization. Bioresource Technology, 71, 63-69. https://doi.org/10.1016/S0960-8524(99)00051-6

[12] Ubalua, A.O. (2007) Cassava Wastes: Treatment Options and Value Addition Alternatives. African Journal of Biotechnology, 6, 2065-2073. https://doi.org/10.5897/AJB2007.000-2319

[13] Food and Agriculture Organization of the United Nations (2016) Report on Cassava Production in the World, FAO-STAT 2016. http://www.fao.org/home/en/

[14] Apiwatanapiwat, W., Prapassorn, R., Pilanee, V., Warunee, T., Kosugi, A., Takamitsu, A., Yutaka, M. and Yoshinori, M. (2013) Ethanol Production at High Temperature from Cassava Pulp by a Newly Isolated Kluyveromyces marxianus Strain, TISTR 5925. Aims Energy, 1, 3-16. https://doi.org/10.3934/energy.2013.1.3

[15] Banerjee, S., Sandeep, M., Ramkrishna, S., Balendu, G., Devanand, S., Tapan, C. and Pandey, R. (2010) Commercializing Lignocellulosic Bioethanol: Technology Bottlenecks and Possible Remedies. Biofuels, Bioproducts and Biorefining, 4, 77-93. https://doi.org/10.1002/bbb.188

[16] Abdel-Banat, B.M., Hoshida, H., Ano, A., Noklang, S. and Akada, R. (2010) High Temperature Fermentation: How Can Processes for Ethanol Production at High Temperatures Become Superior to the Traditional Process Using Mesophilic Yeast? Applied Microbiology and Biotechnology, 85, 861-867. https://doi.org/10.1007/s00253-009-2248-5

[17] Dhaliwal, S.S., Oberoi, H.S., Sandhu, S.K., Nanda, D., Kumar, D. and Uppal, S.K. (2011) Enhanced Ethanol Production from Sugarcane Juice by Galactose Adaptation of a Newly Isolated Thermotolerant Strain of Pichia kudriavzevii. Bioresource Technology, 102, 5968-5975. https://doi.org/10.1016/j.biortech.2011.02.015

[18] Napatchanok, Y., Yongmanitchai, W., Yamada, M. and Limtong, S. (2013) Selection and Characterization of a Newly Isolated Thermotolerant Pichia kudriavzevii Strain for Ethanol Production at High Temperature from Cassava Starch Hydrolysate. Antonie van Leeuwenhoek, 103, 577-588. https://doi.org/10.1007/s10482-012-9842-8

[19] Chutima, K., Dethoup, T. and Limtong, S. (2014) Ethanol Production from Cassava Using a Newly Isolated Thermotolerant Yeast Strain. Science Asia, 40, 268-277. 
https://doi.org/10.2306/scienceasia1513-1874.2014.40.268

[20] Johannes, T.W, Woodyer, R.D. and Zhao, H. (2006) High-Throughput Screening Methods Developed for Oxidoreductases, In: Reymond, J.-L., Ed., Enzyme Assays. High-Throughput Screening, Genetic Selection and Fingerprinting, Wiley-VCH Verlag GmbH \& Co. KGaA, Weinheim, 77-93.

[21] Saitou, N. and Nei, M. (1987) The Neighbor-Joining Method: A New Method for Reconstructing Phylogenetic Trees. Molecular Biology and Evolution, 4, 406-425.

[22] Tamura, K., Nei, M. and Kumar, S. (2004) Prospects for Inferring Very Large Phylogenies by Using the Neighbor-Joining Method. Proceedings of the National Academy of Sciences, 101, 11030-11035. https://doi.org/10.1073/pnas.0404206101

[23] Tamura, K., Stecher, G., Peterson, D., Filipski, A. and Kumar, S. (2013) MEGA6: Molecular Evolutionary Genetics Analysis Version 6.0. Molecular Biology and Evolution, 30, 2725-2729. https://doi.org/10.1093/molbev/mst197

[24] Updegraff, M.D. (1969) Semimicro Determination of Cellulose in Biological Materials. Analytical Biochemistry, 32, 420-424. https://doi.org/10.1016/S0003-2697(69)80009-6

[25] Kurtzman, C.P. and Fell, J.W. (1998) The Yeasts: A Taxonomic Study. Elsevier Science, Amsterdam, 77-100.

[26] Ballesteros, M., Oliva, J.M., Negro, M.J., Manzanares, P. and Ballesteros, I. (2004) Ethanol from Lignocellulosic Materials by a Simultaneous Saccharification and Fermentation Process (SFS) with Kluyveromyces marxianus CECT 10875. Process Biochemistry, 39, 1843-1848. https://doi.org/10.1016/j.procbio.2003.09.011

[27] Limtong, S., Sringiew, C. and Yongmanitchai, W. (2007) Production of Fuel Ethanol at High Temperature from Sugar Cane Juice by a Newly Isolated Kluyveromyces marxianus. Bioresource Technology, 98, 3367-3374. https://doi.org/10.1016/j.biortech.2006.10.044

[28] Oberoi, H., Singh, N., Babbar, S., Kaur, S., Sandeep, S.D., Kaur, U., Chadha, B.S. and Bhargav, V.K. (2012) Ethanol Production from Alkali-Treated Rice Straw via Simultaneous Saccharification and Fermentation Using Newly Isolated Thermotolerant Pichia kudriavzevii HOP-1. Journal of Industrial Microbiology and Biotechnology, 39, 557-566. https://doi.org/10.1007/s10295-011-1060-2

[29] Ceccato-Antonini, S.R. (2008) Biotechnological Implication of Filamentation in Saccharomyces cerevisiae. Biotechnology Letters, 30, 1151-1161.

https://doi.org/10.1007/s10529-008-9681-x

[30] Gallardo, J.C.M., Souza, C.S., Cicarelli, R.M.B., Oliveira, K.F., Morais, M.R. and Laluce, C. (2011) Enrichment of a Continuous Culture of Saccharomyces cerevisiae with the Yeast Issatchenkia orientalis in the Production of Ethanol at Increasing Temperatures. Journal of Industrial Microbiology and Biotechnology, 38, 405-414. https://doi.org/10.1007/s10295-010-0783-9

[31] Chompunuch, V., Ouephanit, C., Burapatana, V. and Chulalaksananukul, W. (2013) Cassava Pulp Enzymatic Hydrolysis Process as a Preliminary Step in Bio-Alcohols Production from Waste Starchy Resources. Journal of Cleaner Production, 39, 273-279. https://doi.org/10.1016/j.jclepro.2012.07.055

[32] Rugthaworn, P., Murata, Y., Machida, M., Apiwatanapiwat, W., Hirooka, A., Thanapase, W., Dangjarean, H., Ushiwaka, S., Morimitsu, K., Kosugi, A., Arai, T. and Vaithanomsat, P. (2014) Growth Inhibition of Thermotolerant Yeast, Kluyveromyces marxianus, in Hydrolysates from Cassava Pulp. Applied Biochemistry and Biotechnology, 173, 197-208. https://doi.org/10.1007/s12010-014-0906-2 
[33] Nwuche, C.O., Murata, Y., Nweze, J.E., Ndubuisi, I.A., Ohmae, H., Saito, M. and Ogbonna, J.C. (2018) Bioethanol Production under Multiple Stress Condition by a New Acid and Temperature Tolerant Saccharomyces cerevisiae Strain LC 269108 Isolated from Rotten Fruits. Process Biochemistry, 67, 105-112.

https://doi.org/10.1016/j.procbio.2018.01.016 